\title{
The Effect of Growth Temperature on Wax Ester Content and Composition of Euglena gracilis
}

\author{
By AKIKO KAWABATA* AND MUTSUKO KANEYAMA \\ Department of Natural Science, Osaka Women's University, Sakai, Osaka 590, Japan
}

(Received 24 May 1988; revised 20 January 1989; accepted 26 January 1989)

\begin{abstract}
A streptomycin-bleached mutant of Euglena gracilis strain Z, a non-photosynthetic mutant, was grown aerobically in the dark at 33,26 and $15^{\circ} \mathrm{C}$ respectively. The content of wax esters was greater at higher growth temperatures, whereas the content of paramylon was greater at lower temperatures. The highest temperature $\left(33^{\circ} \mathrm{C}\right)$ caused the greatest accumulation of wax esters. Wax esters synthesized at the highest temperature had carbon chain lengths of C24-32 and the predominant chain lengths were $\mathrm{C} 27$ and $\mathrm{C} 28$. The constituent fatty acids and alcohols ranged from $\mathrm{C} 11$ to $\mathrm{C} 18$ with myristic acid and myristyl alcohol being the main components. At the lowest temperature $\left(15^{\circ} \mathrm{C}\right)$ the mean chain length of wax esters decreased. The most abundant wax ester was $\mathrm{C} 26$, and the most abundant fatty acids and fatty alcohols of wax esters were $\mathrm{C} 13$. A considerable amount (44-48\% of the total) of odd-carbon-numbered wax esters were present. The effect of temperature on odd-carbon-numbered wax formation is discussed in relation to possible sources of propionate or methylmalonate units.
\end{abstract}

\section{INTRODUCTION}

The unicellular photosynthetic protist Euglena gracilis has a multifunctional fatty acid synthetase in the cytoplasm (Delo et al., 1971; Goldberg \& Bloch, 1972), two acyl-carrierprotein-dependent systems in the chloroplasts (one of the two systems is a chain elongation system) (Goldberg \& Bloch, 1972), a fatty acid synthetase in the microsomes (Nagai \& Bloch, $1965)$ and a novel malonyl-CoA-independent fatty acid synthetase system in the mitochondria (Inui et al., 1984). Differences in the illumination regime during growth of $E$. gracilis can cause changes in both the chain length (Rosenberg, 1963; Rosenberg \& Pecker, 1964; Rosenberg et al., 1965) and the degree of unsaturation (Hulanicka et al., 1964; Rosenberg \& Gouaux, 1967; ErnstFonberg \& Bloch, 1971; Pohl, 1973) of fatty acids. Inui et al. (1982) demonstrated a direct correlation between anaerobiosis and concomitant wax ester synthesis. However, the effect of environmental temperature on the regulation of lipid synthesis in Euglena has not been studied. The present experiments were planned to investigate the effect of temperature on the content and composition of wax esters, as part of a study of the effects of temperature on fatty acid metabolism in E. gracilis.

\section{METHODS}

Chemicals. Fatty acid methyl ester standards and alcohol standards were purchased from Wako Pure Chemical Industries, Tokyo Kasei and Sigma. Wax ester standards were synthesized by heating overnight equimolar mixtures of fatty acid methyl esters and fatty alcohols in n-hexane (Hashimoto et al., 1967). They were purified by column chromatography on silica gel, eluted with $n$-hexane, followed by hexane/benzene $(1: 1, v / v)$ and methanol in succession. The hexane/benzene fraction contained the wax esters.

Organism and culture. To eliminate the effect of light, a streptomycin-bleached mutant of E. gracilis strain Z (Oda et al., 1982) was used. As described in a previous paper (Kawabata et al., 1982), the cells were adapted to 33, 26 , or $15^{\circ} \mathrm{C}$ by successive cultivation at these temperatures. Cells were grown in $150 \mathrm{ml}$ of Koren-Hutner medium (Koren \& Hutner, 1967) in $500 \mathrm{ml}$ flat-shouldered flasks on a shaker $\left(120\right.$ strokes $\left.\mathrm{min}^{-1}\right)$ in the dark at the above 
temperatures. Growth was determined by cell counts using a haemocytometer. Dissolved oxygen in the culture medium was determined using a Clark-type oxygen electrode.

Preparation and analysis of lipids. The cells were collected by centrifugation at 3000 r.p.m. for 2 min and washed twice with $1 \%(\mathrm{w} / \mathrm{v}) \mathrm{NaCl}$. Lipids were extracted from the cells by the method of Bligh \& Dyer (1959). Lipid extracts were dried under nitrogen. Wax esters were purified from the lipid extract by thin-layer chromatography (TLC) using silica gel (Merck) plates with a solvent system containing n-hexane/diethyl ether $(3: 2$, v/v) or $\mathrm{n}$-hexane/diethyl ether/acetic acid $\left(80: 20: 1\right.$, by vol.). The wax-ester-containing spots $\left(R_{F}\right.$ values 0.8 and 0.7 respectively in the two solvent systems) were scraped off the TLC plates and extracted three times with diethyl ether. The wax esters were dried under nitrogen, dissolved in $n$-hexane, and samples analysed by gas-liquid chromatography (GLC) on $5 \%(\mathrm{w} / \mathrm{v})$ Thermon-1000 packed in a $3 \times 225 \mathrm{~mm}$ (int. diam.) glass column operated at $240^{\circ} \mathrm{C}$ in a Yanako model G-80 chromatograph equipped with a hydrogen detector. The carrier gas was $\mathrm{N}_{2}$, used at a flow rate of $20 \mathrm{ml} \mathrm{min}^{-1}$. The injection temperature was $280^{\circ} \mathrm{C}$ and the detector temperature $320^{\circ} \mathrm{C}$. Decyl decanoate, octyl myristate, stearyl stearate and myristyl myristate, prepared as described above, were used as internal standards. The purified wax ester mixture was saponified with $0.5 \mathrm{M}-\mathrm{KOH}$ in $95 \%(\mathrm{v} / \mathrm{v})$ aqueous methanol at $70-75^{\circ} \mathrm{C}$ for $4 \mathrm{~h}$, then dried under nitrogen, after which water and $\mathrm{n}$-hexane were added. After shaking, the $n$-hexane layer was collected and used as the fatty alcohol fraction. The aqueous layer was acidified to $\mathrm{pH} 1.6$ with $3 \mathrm{M}-\mathrm{HCl}$ and the wax fatty acids were extracted three time with $\mathrm{n}$-hexane. The free alcohols were converted to their acetates with acetic anhydride (Farquhar, 1962). The fatty acids were methylated with $5 \%(w / v)$ methanolic hydrochloric acid solution at $80-90{ }^{\circ} \mathrm{C}$ for $1 \mathrm{~h}$ (Stoffel et al., 1959). The wax fatty acid esters and fatty alcohol acetates were separated and identified by GLC on $10 \%(w / v)$ DEGS and $5 \%(w / v)$ Advance DS (Shimazu) packed in a $3 \times 150 \mathrm{~mm}$ (int. diam.) glass column. The column temperature was maintained at $120^{\circ} \mathrm{C}$ for the first $1 \mathrm{~min}$ and then was increased from 120 to $210^{\circ} \mathrm{C}$ at $4{ }^{\circ} \mathrm{C} \mathrm{min}-1$. The carrier gas flow rate, the injection temperature and the detector temperature were as in the GLC of wax esters.

Wax esters, fatty acid esters and fatty alcohol acetates were hydrogenated with palladium oxide as the catalyst in 2-3 $\mathrm{ml}$ ethanol at room temperature for $1 \mathrm{~h}$ until the iodine value was zero.

Paramylon estimation. Paramylon was measured using the method described in Kawabata et al. (1982).

\section{RESULTS}

\section{Effects of temperature on growth and cellular constituents}

Growth curves of the bleached mutant of E. gracilis strain $\mathrm{Z}$ cultured at 33,26 and $15^{\circ} \mathrm{C}$ in the dark with shaking are shown in Fig. 1(a). The generation times were 14.8, 15.7 and $35 \mathrm{~h}$ for the cells grown at 33,26 and $15^{\circ} \mathrm{C}$, respectively. Cultures grown at $15^{\circ} \mathrm{C}$ completed the exponential phase after about $18 \mathrm{~d}$, those at $26^{\circ} \mathrm{C}$ after about $6 \mathrm{~d}$ and at $33^{\circ} \mathrm{C}$ after about $5 \mathrm{~d}$. The cell number of the cultures grown at $15^{\circ} \mathrm{C}$ was slightly higher than that of the cultures grown at $26^{\circ} \mathrm{C}$. The temperature affected only the growth rate and the generation time but not cell yield, since weight and size of the cells grown at $33^{\circ} \mathrm{C}$ were twice those of the cells grown at 15 or $26^{\circ} \mathrm{C}$. The concentrations of wax esters and paramylon in cultures grown at 33,26 and $15^{\circ} \mathrm{C}$ are shown in Fig. 1(b). The paramylon content was highest in the cells grown at $15^{\circ} \mathrm{C}$ and lowest in those grown at $33{ }^{\circ} \mathrm{C}$, which contained about $50 \%$ of the paramylon present in the cells grown at $15^{\circ} \mathrm{C}$. In contrast, the contents of the total lipids and wax esters showed a reverse relationship, being higher at $33^{\circ} \mathrm{C}$ and lower at $15^{\circ} \mathrm{C}$; the wax ester content of cells grown at $33^{\circ} \mathrm{C}$ was seven times as much as those grown at $15^{\circ} \mathrm{C}$. However, the content of the polar lipids was almost constant in comparison with the increased contents of total lipids and wax esters.

\section{Effect of temperature on the content and composition of wax esters}

The wax ester contents of bleached cells of E. gracilis grown at 33,26 and $15^{\circ} \mathrm{C}$ were 108,23 and $14 \mu \mathrm{g}$ per $10^{6}$ cells, respectively.

The analysis by GLC of wax esters formed by $E$. gracilis grown at different temperatures is shown in Table 1 . The wax esters in cells grown at the lowest temperature $\left(15^{\circ} \mathrm{C}\right)$ were composed mainly of $\mathrm{C} 26$ and $\mathrm{C} 27$ esters $(52 \%$ of the total), and the percentage of $\mathrm{C} 28$ esters was less than in the cells grown at 26 or $33^{\circ} \mathrm{C}$. The cells grown at 26 or $33^{\circ} \mathrm{C}$ contained mainly $\mathrm{C} 27$ and $\mathrm{C} 28$ esters ( 49 and $55 \%$, respectively, of the total). The mean carbon chain-lengths of the wax esters of cells grown at 15,26 and $33{ }^{\circ} \mathrm{C}$ were $26.5,27.5$ and $27 \cdot 6$, respectively, indicating that the wax esters at the lowest temperature were shorter at the $2 \%$ significance level than those from cells grown at the highest temperature. At $15{ }^{\circ} \mathrm{C}$ approximately $50 \%$ of the wax esters had odd carbon-numbers. 

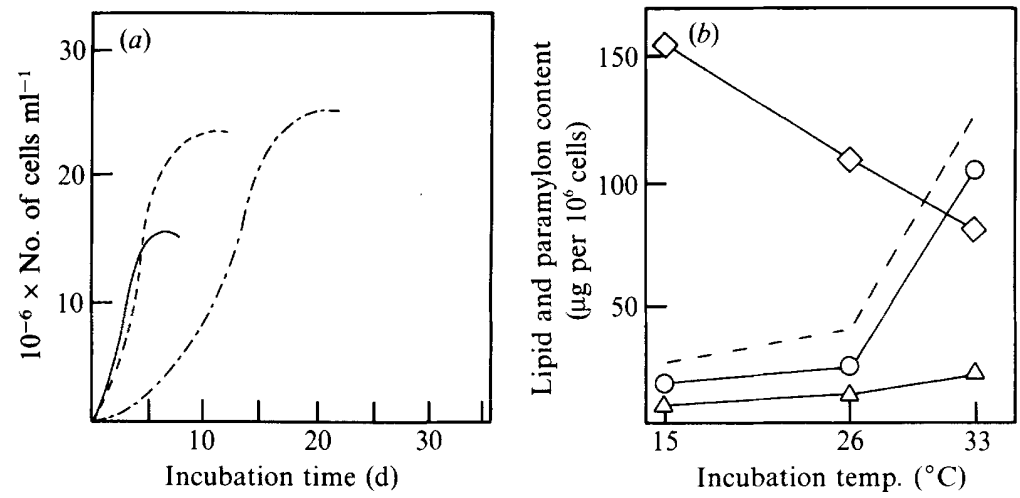

Fig. 1. (a) Growth curves of the bleached mutant of E. gracilis cultured at different temperatures. ---.--, $15^{\circ} \mathrm{C} ;---, 26^{\circ} \mathrm{C} ;-, 33^{\circ} \mathrm{C}$. (b) Effect of temperature on the contents of total lipids (---), polar lipids, $(\triangle)$, wax esters $(\bigcirc)$ and paramylon $(\diamond)$ in $E$. gracilis.

Table 1. Effect of temperature on chain-length of wax esters in E. gracilis

Each value is the mean of five experiments ( $\mathrm{SD} \leqslant 12 \%$ ). tr., Trace.

\begin{tabular}{|c|c|c|c|c|c|}
\hline \multirow[b]{2}{*}{$\begin{array}{l}\text { Carbon-chain } \\
\text { length }\end{array}$} & \multirow[b]{2}{*}{$\begin{array}{l}\text { Culture } \\
\text { conditions }\end{array}$} & \multicolumn{4}{|c|}{ Wax ester composition (weight $\%$ ) } \\
\hline & & $15^{\circ} \mathrm{C}$ & $26{ }^{\circ} \mathrm{C}$ & $33^{\circ} \mathrm{C}$ & $\begin{array}{c}27^{\circ} \mathrm{C} \\
\text { (anaerobiosis)* }\end{array}$ \\
\hline 23 & & $2 \cdot 1$ & 0.7 & $0 \cdot 8$ & $\operatorname{tr}$ \\
\hline 24 & & $6 \cdot 3$ & $2 \cdot 3$ & 1.8 & $0 \cdot 1$ \\
\hline 25 & & $15 \cdot 4$ & 6.6 & 4.9 & 0.8 \\
\hline 26 & & $27 \cdot 4$ & $19 \cdot 0$ & $15 \cdot 3$ & $6 \cdot 1$ \\
\hline 27 & & $24 \cdot 3$ & 24.0 & $26 \cdot 2$ & $17 \cdot 2$ \\
\hline 28 & & $15 \cdot 1$ & 25.0 & 29.0 & 36.0 \\
\hline 29 & & 5.5 & 10.5 & 11.5 & $19 \cdot 0$ \\
\hline 30 & & $3 \cdot 2$ & 7.3 & 7.0 & $15 \cdot 2$ \\
\hline 31 & & 0.7 & $2 \cdot 8$ & $2 \cdot 3$ & 3.7 \\
\hline 32 & & tr. & 1.8 & $1 \cdot 2$ & 1.9 \\
\hline 33 & & tr. & tr. & tr. & tr. \\
\hline $\begin{array}{c}\text { Total } \\
\text { odd-numbered }\end{array}$ & & $48 \cdot 0$ & $44 \cdot 6$ & $45 \cdot 7$ & $40 \cdot 7$ \\
\hline $\begin{array}{c}\text { Mean } \\
\text { chain-length }\end{array}$ & & $26 \cdot 5$ & 27.5 & 27.6 & $28 \cdot 4$ \\
\hline
\end{tabular}

After saponification, the component fatty acids and alcohols were identified by GLC (Table 2). The constituent fatty acids and alcohols ranged from $\mathrm{C} 11$ to $\mathrm{C} 18$. In the cells grown at 26 and $33{ }^{\circ} \mathrm{C}$ the main components were myristic acid and myristyl alcohol $\left(42 \%\right.$ of the total). At $15{ }^{\circ} \mathrm{C}$ the predominant fatty acids and alcohols were $\mathrm{C} 13,(40$ and $43 \%$ of the total). Approximately $50 \%$ of the fatty acids and $54 \%$ of the fatty alcohols of cells grown at $15{ }^{\circ} \mathrm{C}$ had odd carbonnumbers. As the temperature increased, the ratios of odd- to even-carbon-number fatty acids and fatty alcohols in the wax esters decreased at the $5 \%$ significance level. However, the ratio of odd- to even-number carbon chains in the polar lipids was little changed by growth temperature. 

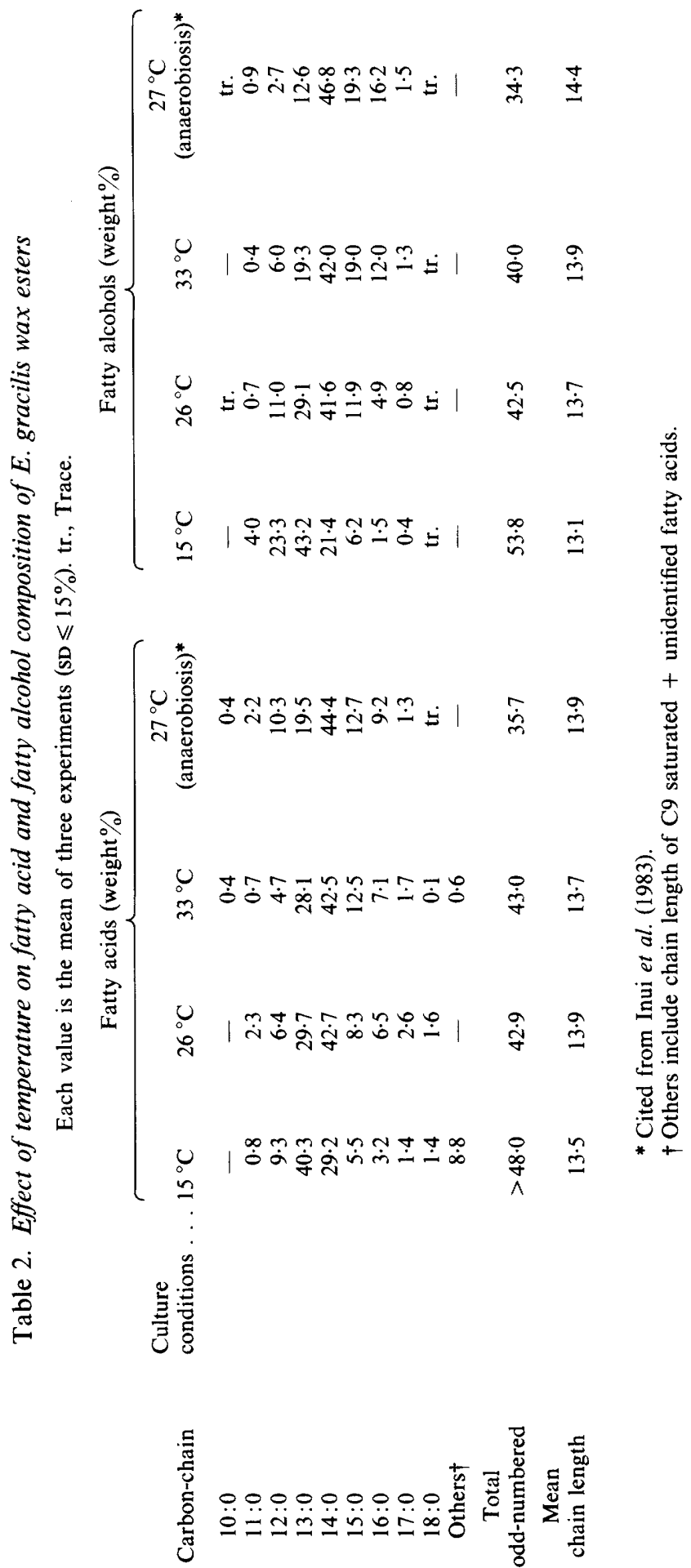


\section{DISCUSSION}

In many unicellular organisms and aquatic animals, the quality and quantity of the lipids depend on the external temperature. At lowered temperatures, the acyl groups of the phospholipids in membranes are more unsaturated in Tetrahymena (Nozawa, 1979), Candida lipolytica (Ferrante et al., 1983) and carp liver (Wodtke, 1978). At elevated temperatures, the total fatty acid increases in Brevibacterium ammoniagenes (Kawaguchi et al., 1979), whereas the ratio of $\mathrm{C} 16$ acid to $\mathrm{C} 18$ acid in yeast (Okuyama et al., 1979) and the total polar lipid contents in Neurospora crassa decrease (Vokt \& Brody, 1985).

Our observations show that growth at low temperature results in the presence of more unsaturated total lipids and polar lipids in Euglena (data not shown), whereas elevated temperatures cause an increase in total lipid content, especially wax esters (Fig. 1b). E. gracilis accumulates wax esters when grown in a carbon-rich medium and under adverse conditions such as anoxia (Inui et al., 1982), darkness (Rosenberg, 1967), lack of agitation (Nagai et al., 1971), ageing (Marcenko, 1978) and thiamin deficiency (Inui et al., 1988). In the present paper, we have shown that the highest growth temperature $\left(33^{\circ} \mathrm{C}\right)$ causes the greatest accumulation of wax esters in E. gracilis.

There are few reports of the temperature-dependent variation of wax ester content or composition in micro-organisms. Russell \& Volkman (1980) reported the effect of growth temperature on wax ester composition in the psychrophilic bacterium Micrococcus cryophilus. At elevated temperature, the mean chain length of wax esters increased and their unsaturation decreased. Our present observations in Euglena agree with the data in $M$. cryophilus. The mean carbon-chain length of wax esters in E. gracilis grown anaerobically (Inui et al., 1983) is higher at the $5 \%$ significance level than when the organism is grown aerobically, even at the highest temperature (Table 1). Inui et al. (1988) reported that thiamin deficiency in the cells results in the formation of wax esters with shorter carbon chains under anaerobic conditions. Wax ester formation occurs under anaerobic conditions, its rapid synthesis being initiated below an $\mathrm{O}_{2}$ concentration of $10^{-6} \mathrm{M}$ (Inui et al., 1982). Hence, wax formation at a high temperature is not necessarily linked to anaerobiosis. In the present experiment, however, the cells were cultured at $33^{\circ} \mathrm{C}$ for $5 \mathrm{~d}$ and the culture medium contained $100 \mu \mathrm{M}$ dissolved oxygen, which is five times higher than that of the $K_{\mathrm{m}}$ of cytochrome oxidase (Barman, 1969). Hence, the dissolved oxygen concentration is sufficient to fulfill the respiratory capacity of Euglena cells.

The significant amounts of wax esters with odd carbon-chain lengths found in the present experiments could arise from $\alpha$-oxidation of even-numbered precursors. However, this has been excluded in the case of Euglena by Schneider et al. (1984). Hence, the odd-numbered fatty acid and fatty alcohol components of wax esters accumulated in the cells are probably synthesized with propionyl-CoA as a primer. There are two main pathways for the synthesis of propionyl$\mathrm{CoA}$. One uses methylmalonyl-CoA as an intermediate, and another, less common, involves acrylyl-CoA. The latter pathway can be excluded for Euglena, since it does not explain the incorporation of $\mathrm{CO}_{2}$ into odd-numbered chains (Schneider \& Betz, 1985). The methylmalonylCoA pathway is the most probable, since its operation in the reverse direction, i.e. in propionate assimilation, has been demonstrated in Euglena by Yokota et al. (1982). Moreover, one additional ATP can be formed in the methylmalonyl pathway (Schneider \& Betz, 1985); therefore propionyl-CoA formation is favourable for the cells. The amount of propionate supplied from branched amino acids or through unknown pathways may increase at higher temperatures. Catabolism of propionate in Euglena mitochondria releases $\mathrm{CO}_{2}$ only in the dark, resulting in loss of carbon (Yokota et al., 1982), but this is preferable to the accumulation of propionate which is toxic.

The increased formation of wax esters at higher temperatures is unique in that they have a relatively high molecular mass and are highly insoluble in water. They are sometimes called crystalloids (Marcenko, 1978), which are present as suspended solids in the cytosol, and apparently do not affect other pathways of metabolism. The wax ester is retained in cells with as little loss of carbon as possible, and when lower temperature conditions are restored the wax esters are rapidly converted back to paramylon (Kawabata et al., 1982). Euglena is very sensitive to temperature (Cook, 1968) so it has developed unique strategies to cope with adverse conditions. 
We thank Drs Shozaboro Kitaoka, Yoshihisa Nakano, Kazutaka Miyatake, Akiho Yokota and Hiroshi Inui, University of Osaka Prefecture, for their encouragement and many suggestions during the course of this work.

\section{REFERENCES}

BARMAN, T. E. (1969). Cytochrome oxidase. In Enzyme Handbook, vol. 1, pp. 223-224. Edited by T. E. Barman. Berlin, Heidelberg, \& New York: SpringerVerlag.

BLIGH, E. G. \& DYER, W. J. (1959). A rapid method of total lipid extraction and purification. Canadian Journal of Biochemistry and Physiology 37, 911-917.

Cook, J. R. (1968). The cultivation and growth of Euglena. In The Biology of Euglena, vol. 1, pp. 243314. Edited by D. E. Buetow. New York: Academic Press.

Delo, J., ERnst-Fonberg, M. L. \& Bloch, K. (1971). Fatty acid synthetases from Euglena gracilis. Archives of Biochemistry and Biophysics 143, 384-391.

ERnst-FonberG, M. L. \& Bloch, K. (1971). A chloroplast-associated fatty acid synthetase system in Euglena. Archives of Biochemistry and Biophysics 143, 392-400.

Ferrante, G., Ohno, Y. \& Kates, M. (1983). Influence of temperature and growth phase on desaturase activity of the mesophilic yeast Candida lipolytica. Canadian Journal of Biochemistry and Cell Biology 61, 171-177.

FARQUHAR, J. W. (1962). Identification and gas-liquid chromatographic behaviour of plasmalogen aldehydes and their acetal, alcohol, and acetylated alcohol derivatives. Journal of Lipid Research 3, 21-30.

GoldberG, I. \& Bloch, K. (1972). Fatty acid synthetases in Euglena gracilis. Journal of Biological Chemistry 247, 7349-7357.

Hashimoto, A., Hirotani, A. \& Mukai, K. (1967). Thin-layer chromatography of true wax. Nippon Nogei-kagaku Kaishi 41, 139-144.

Hulanicka, D., Erwin, J. \& Bloch, K. (1964). Lipid metabolism of Euglena gracilis. Journal of Biological Chemistry 239, 2778-2787.

InUi, H., MiYatake, K., NaKano, Y. \& Kitaoka, S. (1982). Wax ester fermentation in Euglena gracilis. FEBS Letters 150, 89-93.

InUI, H., Miyatake, K., NaKano, Y. \& Kitaoka, S. (1983). Production and composition of wax esters by fermentation of Euglena gracilis. Agricultural and Biological Chemistry 47, 2669-2671.

InUi, H., Miyatake, K., Nakano, Y. \& Kitaoka, S. (1984). Fatty acid synthesis in mitochondria of Euglena gracilis. European Journal of Biochemistry 142, 121-126.

InUI, H., OChI, H., Nogami, K., Miyatake, K., NAKANO, Y. \& KITAOKA, S. (1988). Effect of thiamin deficiency on wax ester fermentation in Euglena gracilis. Agricultural and Biological Chemistry 52, 49-54.

KaWaguchi, A., Seyama, Y., SaSaki, K., OKuda, S. \& YAMAKAWA, T. (1979). Thermal regulation of fatty acid synthetase from Brevibacterium ammoniagenes. Journal of Biochemistry 85, 865-869.

Kawabata, A., Miyatake, K. \& Kitaoka, S. (1982). Effect of temperature on the contents of two energyreserve substances, paramylon and wax esters, in Euglena gracilis. Journal of Protozoology 29, 421-423.
Koren, L. E. \& Hutner, S. H. (1967). High-yield media for photosynthesizing Euglena gracilis $Z$. Journal of Protozoology 14, Suppl. 17.

MaRCENKo, E. (1978). Cristalloid bodies in Euglena. European Journal of Cell Biology 16, 485-493.

NAGAI, J. \& BlOCH, K. (1965). Synthesis of oleic acid by Euglena gracilis. Journal of Biological Chemistry 240, 3702-3703.

NAGAI, J., OHTA, T. \& SAITo, E. (1971). Incorporation of propionate into wax esters by etiolated Euglena. Biochemical and Biophysical Research Communications 42, 523-529.

NozaWA, Y. (1979). Regulatory mechanisms of membrane lipids. With reference to environmental adaptation. Seikagaku 51, 314-347.

OdA, Y., NAKANo, Y. \& KitAoKA, S. (1982). Utilization and toxicity of exogenous amino acids in Euglena gracilis. Journal of General Microbiology 128, 853-858.

Okuyama, H., Saito, M., Joshi, V. C., Gunsberg, S. \& WAKIL, S. J. (1979). Regulation by temperature of the chain length of fatty acids in yeast. Journal of Biological Chemistry 254, 12281-12284.

PoHL, P. (1973). Light-induced changes of radioactivities in the ${ }^{14} \mathrm{C}$-labeled lipids and fatty acids of dark grown Euglena gracilis. Zeitschrift für Naturforschung 28c, $270-284$.

RosenberG, A. (1963). A comparison of lipid pattern in photosynthesizing and nonphotosynthesizing cells of Euglena gracilis. Biochemistry 2, 1148-1154.

ROSENBERG, A. (1967). A novel lipid energy reserve and arachidonic acid enrichment during fasting. Science 157, 1189-1191.

Rosenberg, A. \& Gouaux, J. (1967). Quantitative and compositional changes in monogalactosyl and digalactosyl diglycerides during light-induced formation of chloroplasts in Euglena gracilis. Journal of Lipid Research 8, 80-83.

Rosenberg, A. \& PECKER, M. (1964). Lipid alterations in Euglena gracilis cells during light-induced greening. Biochemistry 3, 254-258.

Rosenberg, A., Pecker, M. \& Moschides, E. (1965). Fatty acids in the pellicles and plastids of lightgrown and dark-grown cells of Euglena. Biochemistry 4, 680-685.

RUSSEll, N. J. \& Volkman, J. K. (1980). The effect of growth temperature on wax ester composition in the psychrophilic bacterium Micrococcus cryophilus ATCC 15174. Journal of General Microbiology 118, 131-141.

SCHNeIder, T., Borkowski, C. \& BetZ, A. (1984). Wax ester formation in Euglena gracilis. during anaerobiosis and photoheterotrophic growth. In Advances in Photosynthesis Research, Vol. 3, pp. 445448. Edited by C. Sybesma. The Hague: M. Nijhoff.

SCHNEIDER, T. \& BETZ, A. (1985). Waxmonoester fermentation in Euglena gracilis $T$. Factors favouring the synthesis of odd-numbered fatty acids and alcohols. Planta 166, 67-73.

Stoffel, W., Chu, F. \& Ahrens, E. H., JR (1959). Analysis of long-chain fatty acid by gas-liquid 
chromatography. Micromethod for preparation of methyl esters. Analytical Chemistry 31, 307-308.

VoKT, J. P. \& BRODY, S. (1985). The kinetics of changes in the fatty acid composition of Neurospora crassa lipids after a temperature increase. Biochimica et biophysica acta 835, 176-182.

WODTKE, E. (1978). Lipid adaptation in liver mitochondrial membranes of carp acclimated to different environmental temperatures. Phospholipid composition, fatty acid pattern, and cholesterol contents. Biochimica et biophysica acta 529, 280-291.

Yokota, A., Hosotani, K. \& Kitaoka, S. (1982). Mechanism of metabolic regulation in photoassimilation of propionate in Euglena gracilis Z. Archives of Biochemistry and Biophysics 213, 530-537. 